\title{
Soil characterisation used in ceramic industries and an analysis of its feasibility in ecological bricks
}

\author{
Caracterização de solos utilizados em indústrias \\ cerâmicas e análise da visibilidade de uso em tijolos \\ ecológicos
}

\section{Abílio José Procópio Queiroz Crislene Rodrigues da Silva Morais}

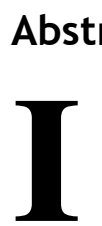
Abstract $\mathrm{n}$ this study, we aimed to characterise soils of three sedimentary deposits used as raw material sources for ceramic industries located in the Brazilian semi-arid region. The samples were collected in deposits located in the cities of Barra de São Miguel, Juazeirinho and Santa Cecília. They were named, prepared and submitted to tests to determine the mineralogical, chemical, physical and thermal characteristics using the XRD, EDX, Casagrande, granulometric analysis, TG and DTA. The soils presented compositions containing quartz, alumina and hematite, predominantly with about $90 \%$ of the total, with well-defined peaks in the diffractograms confirming the statement, and averages of plasticity and granulometric distribution that fit them as silt-clay. When heated to $1000{ }^{\circ} \mathrm{C}$, fire losses were $17 \%, 16 \%$ and $29 \%$ for samples from Barra de São Miguel, Juazeirinho and Santa Cecília, respectively, which is due to the dehydration and burning of organic matter. Thus, they have met the requirements of the Brazilian standards that deal to produce sealing (with sintering) and soil-cement bricks (by pressing). The studied deposits offer satisfactory raw material for the ceramics industry and can provide soil for soil-cement brick (ecological bricks) production.

Keywords: Soil evaluation. Mineralogy. Semi-arid soils. Particle size analysis.

\section{Resumo}

Neste estudo, objetivamos caracterizar solos de três depósitos sedimentares utilizados como fontes de matéria-prima para indústrias de cerâmica localizadas no semiárido brasileiro. As amostras foram coletadas em depósitos localizados nos municípios de Barra de São Miguel, Juazeirinho e Santa Cecília, nomeadas, preparadas e submetidas a testes para determinação das características mineralógicas, químicas, físicas e térmicas pelas técnicas XRD, EDX, Casagrande, análise granulométrica, TG e DTA. As composições dos solos continham quartzo, alumina e hematita, predominantemente, cerca de $90 \%$ do total, com picos bem definidos nos difratogramas que confirmam a afirmação, e apresentaram plasticidade e distribuição médias de grãos que os

${ }^{1}$ Abílio José Procópio Queiroz ${ }^{1}$ Universidade Federal do Sul da Bahia Itabuna - BA - Brasil

\footnotetext{
${ }^{2}$ Crislene Rodrigues da Silva

Morais

2Universidade Federal de Campina

Campina Grande - PB - Brasil
}

Recebido em 10/03/20 Aceito em 22/02/21 encaixam como silto-argilosos. Quando aquecidas até $1000{ }^{\circ} \mathrm{C}$, as perdas ao fogo foram de 17\%, 16\% e 29\% para as amostras de Barra de São Miguel, Juazeirinho e Santa Cecília, percentual devido à desidratação e queima de matéria orgânica. Assim, os solos estudados atenderam aos requisitos das normas brasileiras que tratam da produção de tijolos de vedação (com sinterização) e de solo-cimento (por prensagem). Os depósitos estudados oferecem matéria-prima satisfatória para a indústria cerâmica e podem fornecer solo para a produção de tijolos solo-cimento (tijolos ecológicos).

Palavras-chave: Avaliação de solos. Mineralogia. Solos do semiárido. Análise de tamanho de partículas. 


\section{Introduction}

Soils are defined as a material layer of variable consistency found above the lithosphere and below the atmosphere containing minerals, organic matter, water, water solutions with other components and air representing, respectively, the solid, liquid and gaseous phases, resulting from physical, chemical and biological processes that decompose the matrix rocks, with variations according to the environmental conditions of each region (KUČERÍK; ČTVRTNÍČKOVÁ; SIWERT, 2013; MILLIOLI et al., 2009; AÑÓN et al., 2007; REGUEIRA et al., 2006). It is a natural resource considered as renewable, but which undergoes constant changes in its characteristics due to inclement weather and, mainly, through direct exploration or the activities that increase erodibility, alter salinity and insert contaminating substances, among others (MARSAN et al., 2019; VAEZI; HASANZADEH; CERDÀ, 2016; WEISSERT; SALMOND; SCHEWENDENMANN, 2016; XIA et al., 2016; KUČERÍK; ČTVRTNÍČKOVÁ; SIWERT, 2013).

Each area of science studies and works the soil in a particular way: biology sees the soil by the conditions that allow the diversity of life, chemistry as a set of organic and inorganic components, engineering on the conditions of resistance and characteristics that allow the extraction for creating construction pieces or utensils of the most diverse uses, agronomy use for cultivation or pastures, among others, also having areas that, from knowledge about soil characteristics defined by others, for example medicinal uses of components of the soil characterized by chemistry (HARTEMINK, 2016). According to Hartemink (2016), each subdiscipline has its own definition for soils, focusing on its scientific line, reinforcing that the definition may be simple or complex, depending on who proposes it.

In this perspective, Bernatek-Jakiel, Kacprzak and Stolarczyk (2016) studied soil characteristics in piping or "piping" activities and their behaviour on the formation of what are defined as "underground pipes" and observed that biological activities, composition, porosity and density have a direct influence on the results. Byre et al. (2016) conducted a study on soil respiration, carbon stock and stocking capacity and the direct linkage of these factors with organic matter decomposition, soil moisture and temperature, showing low stability for large areas, specifically in the southeastern United States. Lessovaia et al. (2016) researched the development of soil in rocks defined as "basic" and "ultrabasic" based on their porosity and mineralogy and showing as a final result that a soil originates more clay minerals with the accumulation of silicate and with less porosity.

In general, many researchers have published results about various soils around the world. By observing some of these, it can be inferred that there is a wide range of fields interested in soils:

(a) evaluation of microbial activities in agricultural volcanic soils contaminated with metals (PARELHO et al., 2016);

(b) analysis of the mobility of land vehicles based on a set of time series on soil moisture, captured by WindSat and LIS satellites and by local sensors (STEVENS; MCKINLEY; VAHEDIFARD, 2016);

(c) dynamic characteristics of soil properties in Robinia pseudoacacia vegetation and coastal eco-restoration (MAO et al., 2016);

(d) effect of soil properties on the absorption of pharmaceutical products by worms (CARTER; RYAN; BOXALL, 2016);

(e) the effect of two pesticides on the biology of a soil subjected to severe drought (FRANCO-ANDREU et al., 2016);

(f) development of food webs in the soil of microbes and nematodes under different agricultural practices during the initial phase of pedogenesis of a Mollisols (LI et al., 2016);

(g) soil temperature dynamics on a basin scale (KUNKEL; WELLS; HANCOCK, 2016);

(h) red ceramics of dangerous sludge composites with smelting sand, glass residues and acid neutralizing salts (MYMRIN et al., 2016);

(i) introduction of corn fibres as reinforcement, aiming at improvements of mechanical properties of cemented soil (TRAN; SATOMI; TAKAHASHI, 2018);

(j) stabilisation of cotton soils, using limestone, volcanic ash and mixtures of these elements, observing physical-mechanical properties, ideal proportions of stabiliser mixtures and changes in related mineralogical phases (CHENG et al., 2018);

(k) investigation of the effect of performance variability of cement treated soil slabs (PAN et al., 2018); and

112 Queiroz, A. J.; Morais, C. R. da S. 
(1) study of anthropic soils in different physical, chemical and climatic conditions to characterise physicochemical properties, focusing on the quality and quantity of organic matter (KERN et al., 2019).

Clays are low-grain minerals with grains of less than $2 \mu \mathrm{m}$ due to the decomposition of sedimentary rocks composed of clay minerals, mainly aluminum and iron silicates, organic materials, soluble salts, oxides and other minerals (SANTOS, 1992, 2009; GUGGENHEIM; MARTIN, 1995; VELDE; MEUNIER, 2008). They are divided fundamentally into three large groups, listed by origin, physicochemical characteristics and use in the production of materials: red, white and refractory (MENEZES; NEVES; FERREIRA, 2001). There is, therefore, a great heterogeneity among the clays, and it can derive several subclassifications of this material (MACEDO et al., 2008). The red clay used to produce bricks and tiles, floor tiles and tiles, exemplifying, respectively, groups of red ceramic materials with porous mass and semi-glazed mass, is called this because after firing at temperature ranges between 800 and $1250{ }^{\circ} \mathrm{C}$, a red color (Figure 1) is obtained justified by the presence of high levels of iron oxide III $\left(\mathrm{Fe}_{2} \mathrm{O}_{3}\right)$ (SANTOS, 1992; CABRAL JUNIOR et al., 2005; VIEIRA; PINHEIRO, 2013; ALONSO-SARTUDE et al., 2012; COSTA, 2014; HAJJAJI et al., 2016). According to Santos (2009), this is a material that, when wet, presents considerable plasticity that allows processing or conformation.

Clay, as a raw material for ceramics, is used to produce light aggregates and has the advantages of offering low density and high strength, which is beneficial for structural parts, even when the parts are sintered at lower temperatures (AYATI et al., 2018).

The red ceramic industry represents $40 \%$ of the Brazilian ceramic segment and consumes about 70,000,000 ton year-1 of raw material, most of which are small industrial plants (MACEDO et al., 2008). The Southeastern and Southern regions of Brazil are the most developed in this activity, but other regions, notably the Northeast, have developed considerably (ASSOCIAÇÃO..., 2015; FEDERAÇÃ̃...; FUNDAÇÃO..., 2013). There is no control over the extraction of natural resources for use as a raw material or input in the ceramic industry, which is not exclusive to this industrial line, as well as the environmental impacts caused after withdrawal, especially during production, resulting in the degradation of the condition soil, water and air (ACCHAR; SILVA; SEGADÃES, 2013; SALEIRO, 2010; PALUDO; SANT'ANNA, 2003). Research on ceramic materials is ongoing, seeking the most diverse technological innovations, some of which are concerned with product improvements linked to the reduction of negative environmental impacts (LIU et al., 2016).

Based on the importance previously described for the ceramic market and the need to gain more in-depth knowledge about materials, the objective of this work was to perform and present a physical and mineralogical characterisation of soils from three sedimentary deposits used as raw material sources for ceramic industries in the state of Paraíba, Brazil.

Figure 1 - Red clay - characteristic coloring

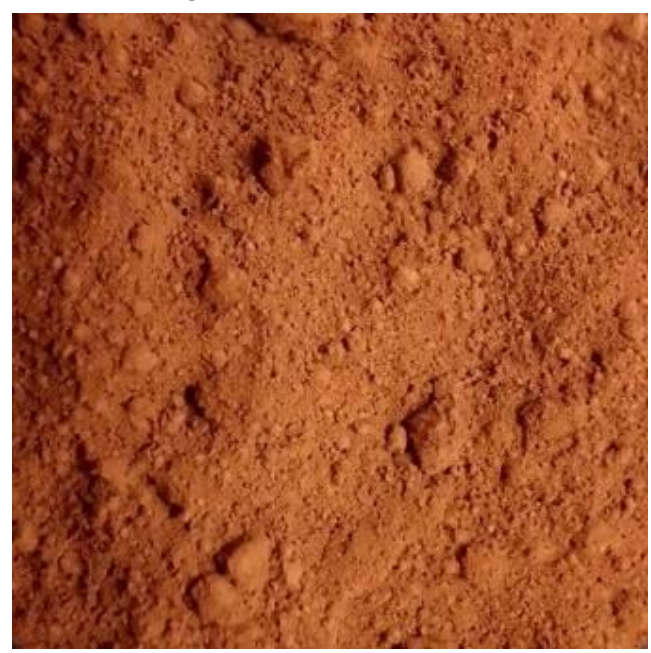




\section{Materials and methods}

\section{Soil sample collections}

Soil samples were collected manually using specific tools such as hoes, shovels and plastic bags for storage. The names of the samples are shown in Table 1, including the coordinates of the collection sites according to the portable GPS of the Garmim ${ }^{\circledR}$ brand, model eTrex 30x.

\section{Particle size analysis}

The determination of the samples grain sizes was done using a Cilas 1064 particle size analyzer. The analyses were performed in a liquid medium (distilled water), with an analysis range of 0.04 to $500 \mu \mathrm{m}$. The tests were carried out to determine the characteristic particle diameters of the samples: mean diameter (dm) and diameters $10 \%\left(\mathrm{~d}_{10}\right), 50 \%\left(\mathrm{~d}_{50}\right)$ and $90 \%\left(\mathrm{~d}_{90}\right)$.

\section{Atterberg boundaries}

The plasticity characteristics - liquidity limit (LL), plasticity limit (PL) and plasticity index (PI) - of the soil samples were determined using the Casagrande method, which is shown in detail in ABNT (2016), NBR 7180/16, considering the results of compliance with the values specified in ABNT (2012a), NBR 10833, when dealing with ecological bricks.

\section{X-Ray Diffraction (XRD)}

The X-ray diffraction technique was used to determine the crystalline phases of the samples of the studied soils.

The diffractograms of the samples were obtained using Shimadzu XDR-6000 equipment, having as analytical conditions the scanning "2theta-theta" or " $2 \theta-\theta$ " of $5^{\circ}$ to $30^{\circ}$, goniometer speed of $2^{\circ}$ min-1, step $0.02^{\circ}$, by the fixed time method, with $\mathrm{CuK} \alpha$ radiation $-40 \mathrm{kV}$ and $30 \mathrm{~mA}$ - and in an aluminum sample port.

\section{Energy Dispersive X-ray fluorescence spectroscopy (EDX)}

The energy dispersive X-ray fluorescence spectroscopy technique was used to determine the chemical composition of soil samples.

The equipment used was the Shimadzu EDX-720 model, which has a rhodium tube (Rh) and readings were made at high voltage $(50 \mathrm{kV})$ and low voltage $(15 \mathrm{kV})$. It detected elements between (Ti-U) and sodium and scandium $(\mathrm{Na}-\mathrm{Sc}$ ) and identified the peaks of energy released by the elements.

The percentage of the oxides $\mathrm{SiO}_{2}, \mathrm{Al}_{2} \mathrm{O}_{3}, \mathrm{Fe}_{2} \mathrm{O}_{3}, \mathrm{~K}_{2} \mathrm{O}, \mathrm{MgO}, \mathrm{CaO}, \mathrm{TiO}_{2}, \mathrm{BaO}, \mathrm{SO}_{3}, \mathrm{MnO}, \mathrm{P}_{2} \mathrm{O}_{5}, \mathrm{SrO}, \mathrm{Rb}_{2} \mathrm{O}$ and $\mathrm{C}$ were determined by the equipment-specific software.

\section{Thermal analysis}

The thermogravimetry (TG) and differential thermal analysis (DTA) techniques were used to determine the characteristics of the masses when submitted to heating, such as fire loss, humidity and organic matter content.

The equipment used was the Shimadzu DTG-60 Simultaneous model (simultaneously performing TG and DTA), with heating at 25 to $1000{ }^{\circ} \mathrm{C}$ at a rate of $10{ }^{\circ} \mathrm{C}$ min-1 in a dynamic $\mathrm{N} 2$ atmosphere.

Table 1 - Detailed identification of samples

\begin{tabular}{c|c|c|c}
\hline Name & Description & Coordinates & Altitude (m) \\
\hline SBSM & $\begin{array}{c}\text { Small dam bed on Angicos Site, } \\
\text { Barra de São Miguel }\end{array}$ & $07^{\circ} 46^{\prime} 02.45^{\prime \prime S} ; 36^{\circ} 21^{\prime} 54.6^{\prime \prime} \mathrm{W}$ & 501 \\
\hline SJUA & Dam bed, city of Juazeirinho & $07^{\circ} 04^{\prime} 48.67^{\prime \prime S} ; 36^{\circ} 35^{\prime} 29.46^{\prime \prime} \mathrm{W}$ & 544 \\
\hline SSCE & $\begin{array}{c}\text { Mining area at Zé de Moura Site, } \\
\text { city of Santa Cecília }\end{array}$ & $07^{\circ} 44^{\prime} 57.05^{\prime \prime S} ; 35^{\circ} 53^{\prime} 34.53^{\prime \prime} \mathrm{W}$ & 560 \\
\hline
\end{tabular}

114 Queiroz, A. J.; Morais, C. R. da S. 
The percentages of mass losses and peak event temperatures were determined in the Shimadzu TA-60 software, version 2.20 .

\section{Results and discussion}

\section{Mineralogical characteristics of soil samples}

The results of the tests by EDX - chemical composition - are shown in Table 2 for the soil samples from Barra de São Miguel, Juazeirinho and Santa Cecília, with the corresponding mass percentages of each of the oxides identified and calculated by the same equipment.

It can be observed that the compositions of the tested soils have the predominance of silica $\left(\mathrm{SiO}_{2}\right.$ or silicon dioxide), alumina $\left(\mathrm{Al}_{2} \mathrm{O}_{3}\right.$ or aluminum oxide) and hematite $\left(\mathrm{Fe}_{2} \mathrm{O}_{3}\right.$ or iron oxide) in common, which totalize in percentages approximately $89.5 \%, 89 \%$ and $86 \%$, respectively, for samples SBSM, SJUA and SSCE, which are considered as characteristic soils of raw material sources of the red ceramic industry. The presence of potassium oxide $\left(\mathrm{K}_{2} \mathrm{O}\right)$, calcium oxide $(\mathrm{CaO})$, magnesium oxide $(\mathrm{MgO})$ and titanium dioxide $\left(\mathrm{TiO}_{2}\right)$ in concentrations between 1 and $5 \%$ were also identified, while other oxides such as sulfur $\left(\mathrm{SO}_{3}\right.$ or sulfur trioxide), manganese oxide II ( $\mathrm{MnO})$, strontium oxide $(\mathrm{SrO})$, rubidium oxide $\left(\mathrm{Rb}_{2} \mathrm{O}\right)$ and carbon $(\mathrm{C})$, appeared in very low concentrations.

Moreover, for SBSM, barium oxide $(\mathrm{BaO})$ and phosphorus pentoxide $\left(\mathrm{P}_{2} \mathrm{O}_{5}\right)$, for soil $\mathrm{B}, \mathrm{P}_{2} \mathrm{O}_{5}$, zirconium $\left(\mathrm{ZrO}_{2}\right.$ or zirconium dioxide), vanadium anhydride $\left(\mathrm{V}_{2} \mathrm{O}_{5}\right)$ (III) and $\mathrm{Y}_{2} \mathrm{O}_{3}$ (yttrium (III) oxide), and for soil $\mathrm{C}$, $\mathrm{ZrO}_{2}, \mathrm{~V}_{2} \mathrm{O}_{5}, \mathrm{Cr}_{2} \mathrm{O}_{3}$, zinc oxide $(\mathrm{ZnO})$ and $\mathrm{Y}_{2} \mathrm{O}_{3}$.

The results of the XRD tests are shown in Figure 2, Figure 3 and Figure 4, respectively, for the soil samples from Barra de São Miguel, Juazeirinho and Santa Cecília, indicating characteristic peaks of elements present in the sample, and shown in Table 3.

Table 2 - Chemical composition of soil samples

\begin{tabular}{c|c|c|c}
\hline \multirow{2}{*}{ Oxides } & \multicolumn{3}{|c}{ Mass (\%) } \\
\cline { 2 - 4 } & SBSM & SJUA & SSCE \\
\hline $\mathrm{SiO}_{2}$ & 56.994 & 51.430 & 48.000 \\
$\mathrm{Al}_{2} \mathrm{O}_{3}$ & 23.133 & 24.334 & 26.000 \\
$\mathrm{Fe}_{2} \mathrm{O}_{3}$ & 9.358 & 13.134 & 12.000 \\
$\mathrm{~K}_{2} \mathrm{O}$ & 2.985 & 4.020 & 2.000 \\
$\mathrm{CaO}$ & 2.950 & 2.037 & 5.000 \\
$\mathrm{MgO}$ & 2.281 & 2.553 & 5.000 \\
$\mathrm{TiO}_{2}$ & 1.124 & 1.745 & 1.000 \\
Other oxides* & 1.175 & 0.747 & 1.000 \\
\hline
\end{tabular}

Note: *other oxides: $\mathrm{MnO}, \mathrm{SO}_{3}, \mathrm{P}_{2} \mathrm{O}_{5}, \mathrm{ZrO}_{2}, \mathrm{BaO}, \mathrm{V}_{2} \mathrm{O}_{5}, \mathrm{SrO}, \mathrm{Cr}_{2} \mathrm{O}_{3}, \mathrm{Rb}_{2} \mathrm{O}, \mathrm{ZnO}$ and $\mathrm{Y}_{2} \mathrm{O}_{3}<0.2 \%$ wt (each).

Figure 2 - Diffractogram of the SBSM

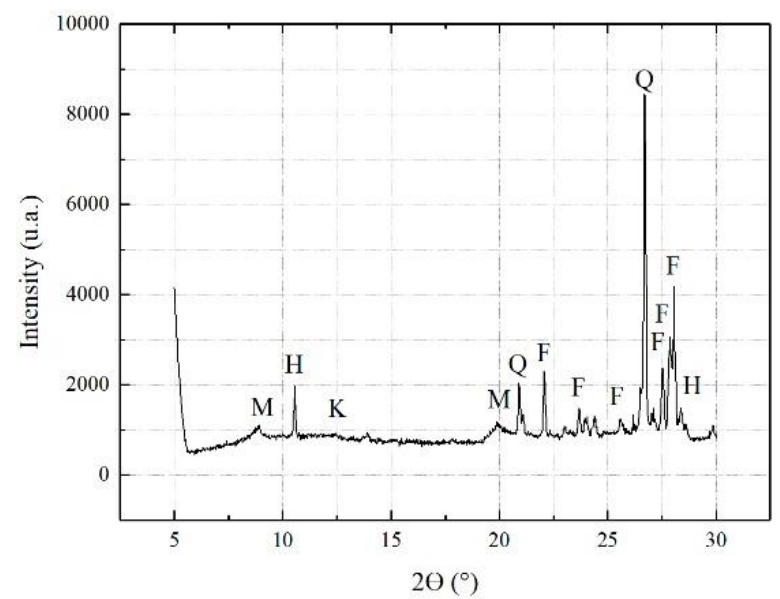

Note: M: mica; H: hematite; K: kaolinite; Q: quartz; and F: feldspar. 
Figure 3 - Diffractogram of the SJUA

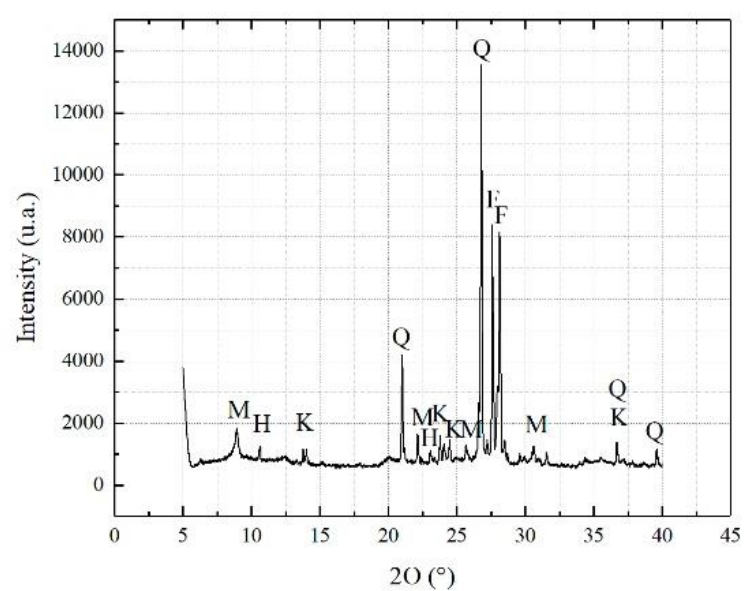

Note: M: mica; H: hematite; K: kaolinite; Q: quartz; and F: feldspar.

\section{Figure 4 - Diffractogram of the SSCE}

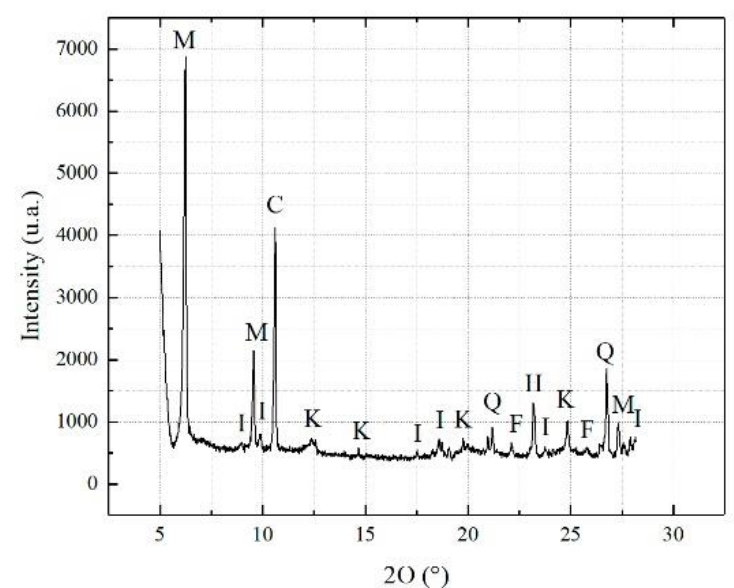

Note: M: mica; I: illite; K: kaolinite; H: hematite; Q: quartz; and F: feldspar.

Analysing the diffractogram of the SBSM, the crystalline phases of quartz $\left(\mathrm{SiO}_{2}\right)$ or "Q", with peaks at $2 \theta=$ $20.92^{\circ}$ and $2 \theta=26.67^{\circ}$ were identified, the latter being the higher relative intensity peak, confirming the highest percentage in the chemical composition of this soil; feldspars or "F", with peaks in $2 \theta=22.09^{\circ}, 2 \theta=$ $23.72^{\circ}, 2 \theta=25.65^{\circ}, 2 \theta 27.42^{\circ}, 2 \theta=27.93^{\circ}$ and $2 \theta=28.06^{\circ}$; kaolinite $\left(\mathrm{Si}_{2} \mathrm{Al}_{2} \mathrm{O}_{5}(\mathrm{OH})_{4}\right)$ or "K", with peaks at $2 \theta=13.88^{\circ}$ and $2 \theta=24.40^{\circ}$; mica or "M", with peaks in $2 \theta=8.89^{\circ}, 2 \theta=17.88^{\circ}$ and $2 \theta=19.85^{\circ}$; and silicaalumina hydroxide $\left(\mathrm{NaCa}_{2}\left(\mathrm{Fe}^{2+} 4 \mathrm{Al}\right) \mathrm{Si}_{6} \mathrm{Al}_{2} \mathrm{O}_{2}(\mathrm{OH})_{2}\right)$ or " $\mathrm{H}$ " with peaks at $2 \theta=10.62^{\circ}$ and $2 \theta=28.47^{\circ}$.

After analysing the SJUA sample (Figure 3), the identified crystalline phases were: quartz with peaks at $2 \theta=$ $21.03^{\circ}$ and $2 \theta=26.81^{\circ}$, whereby the latter was the higher relative intensity peak, also confirming the higher percentage in the chemical composition of this soil; feldspars, with peaks at $2 \theta=27.63^{\circ}$ and $2 \theta=27.99^{\circ}$; kaolinite, with peaks at $2 \theta=13.82^{\circ}, 2 \theta=13.88^{\circ}, 2 \theta=13.88^{\circ}$ and $2 \theta=24.40^{\circ}$; mica, with peaks at $2 \theta=$ $8.89^{\circ}, 2 \theta=17.88^{\circ}$ and $2 \theta=19.85^{\circ}$; and silica-alumina hydroxide with peaks at $2 \theta=10.62^{\circ}$ and $2 \theta=28.47^{\circ}$.

In the diffractogram of the SSCE (Figure 4), the crystalline phases of quartz, with peaks at $2 \theta=20.92^{\circ}$ and $2 \theta=26.67^{\circ}$ were identified, the latter being the peak of greatest relative intensity, confirming the highest percentage in the chemical composition of this soil; feldspars, with peaks in $2 \theta=22.09^{\circ}, 2 \theta=23.72^{\circ}, 2 \theta=$ $25.65^{\circ}, 2 \theta 27.42^{\circ}, 2 \theta=27.93^{\circ}$ and $2 \theta=28.06^{\circ}$; kaolinite, with peaks at $2 \theta=13.88^{\circ}$ and $2 \theta=24.40^{\circ}$; mica, with peaks at $2 \theta=8.89^{\circ}$ (this coinciding with the illite), $2 \theta=17.88^{\circ}$ and $2 \theta=19.85^{\circ}$; and silica-alumina hydroxide with peaks at $2 \theta=10.62^{\circ}$ and $2 \theta=28.47^{\circ}$.

According to Carreiro et al. (2016), Santos (2016), Luz et al. (2005) and Santos (1992), the kaolinite, a phase found in all studied samples, is responsible for providing plasticity of the mass and mechanical resistance to the shaped bodies in red ceramic masses. The quartz phase in the ceramic mass, in turn, offers, 
among others, the characteristics of chemical stability and hardness, probably due to the crystal ordering, to the pieces produced (MASON; THOMPSON, 2010). Thus, the soil samples from Barra de São Miguel, Juazeirinho and Santa Cecília present essential characteristics to produce ceramic pieces: plasticity and stability. Specifically observing the work with red ceramics, the iron oxide III contents confirms these characteristics for the material.

\section{Physical characteristics of samples}

The results of the Casagrande tests for the Atterberg limits - liquidity limit (LL) and plasticity limit (PL) are shown in detail in Appendix D, and summarized in Table 3, including the results of the plasticity index of samples SBSM, SJUA and SSCE.

According to the soil classification ranges from the plasticity index (which reports how clayey a soil is), presented by Caputo (1988), the soil samples studied are therefore all framed in the "medium plastic" range, as they show PI values between $7 \%$ and $15 \%$.

Based on the classification given by Doat et al. (1979), the soils are classified as "silty soil", since they have PI between $5 \%$ and $25 \%$ and LL between $20 \%$ and $50 \%$.

In the Unified Soil Classification System (USCS), these soils are classified as inorganic clays of medium plasticity, code "CL", because LL values are between 30 and $50 \%$.

Another classification is given by the Highway Research Board (HRB), which shows the results obtained for the soil samples of the deposits from Barra de São Miguel and Santa Cecilia classifying them as "A-6" (clay soils). The results obtained from the Juazeirinho deposit soil sample only fit this in the case of rounding the results as all the classifications provide $\mathrm{LL}=40 \%$ as the maximum value, $41 \%$ as the minimum value, $\mathrm{PI}=$ $10 \%$ as the maximum value and $11 \%$ as the minimum value. Therefore, with approximations, all soils are classified as clayey, defining their physical similarity.

It is also worth mentioning plasticity data, based on NBR 8491, in which all the soils worked in this research (after preparation) meet the requirements for soil-cement brick production in manual or hydraulic pressing because they have LL $\leq 45 \%$ and $\mathrm{PI} \leq 18 \%$ (ABNT, 2012b).

Regarding granulometry, the results of the granulometric analysis with the characteristic curve are presented in Figure 5 for the Barra de São Miguel sample, Figure 6 for Juazeirinho and in Figure 7 for Santa Cecilia. Moreover, Table 4 shows the characteristic particle diameters of these soils.

Table 3 - Atterberg limits of the soil samples studied

\begin{tabular}{c|c|c|c}
\hline Sample & Liquidity limit (LL) & Plasticity limit (PL) & Plasticity index (PI) \\
\hline SBSM & $36.17 \pm 4.25 \%$ & $25.00 \pm 8.33 \%$ & $11.17 \pm 8.49 \%$ \\
SJUA & $40.01 \pm 1.86 \%$ & $29.19 \pm 4.84 \%$ & $10.82 \pm 3.93 \%$ \\
SSCE & $32.45 \pm 7.88 \%$ & $19.33 \pm 8.94 \%$ & $11.43 \pm 4.48 \%$ \\
\hline
\end{tabular}

Figure 5 - Diffractogram of the SBSM

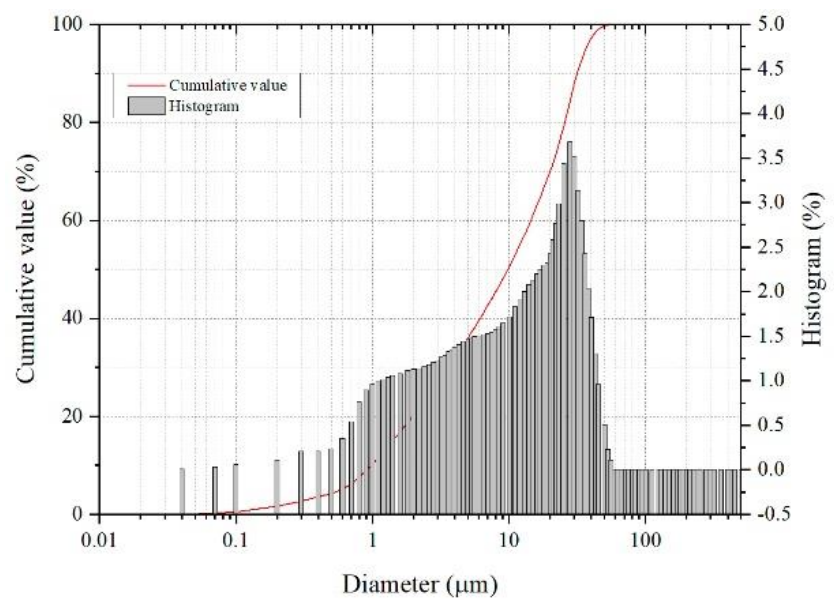

Soil characterisation used in ceramic industries and an analysis of its feasibility in ecological bricks 
Figure 6 - Diffractogram of the SJUA

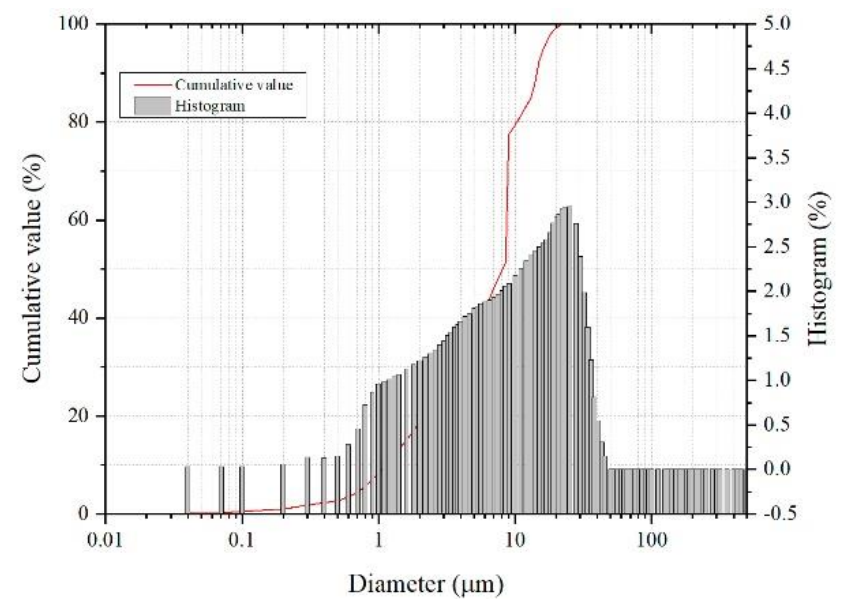

Figure 7 - Diffractogram of the SSCE

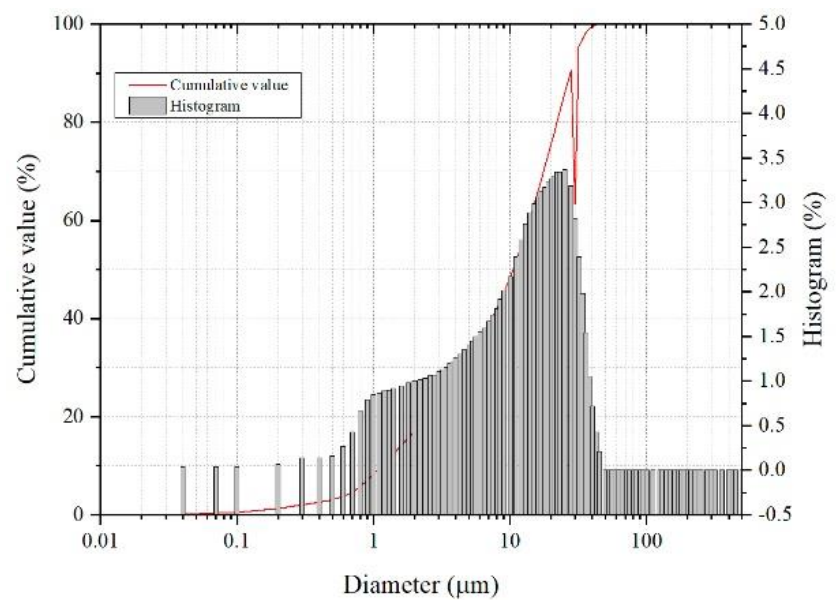

Table 4 - Characteristic particle diameters

\begin{tabular}{c|c|c|c|c}
\hline Sample & $\mathbf{d}_{\mathbf{1 0}}(\boldsymbol{\mu} \mathbf{m})$ & $\mathbf{d}_{\mathbf{5 0}}(\boldsymbol{\mu} \mathbf{m})$ & $\mathbf{d}_{\mathbf{9 0}}(\boldsymbol{\mu} \mathbf{m})$ & $\mathbf{d}_{\mathbf{m}}(\boldsymbol{\mu} \mathbf{m})$ \\
\hline SBSM & 0.97 & 9.80 & 31.67 & 13.57 \\
SJUA & 1.12 & 8.10 & 26.23 & 11.17 \\
SSCE & 1.15 & 10.52 & 27.61 & 12.56 \\
\hline
\end{tabular}

Since the fraction with grains up to $2 \mu \mathrm{m}$ is defined as clay, this corresponds to $20.23 \%$ of the total volume of the soil sample SBSM, $18.73 \%$ of the sample of SJUA and $17.15 \%$ of the SSCE, while in the same order, the fraction with particle sizes between 2 and $60 \mu \mathrm{m}$ in diameter, defined as silt, characterizes $79.77 \%$, $81.27 \%$ and $82.85 \%$ (SANTOS, 1992; ABNT, 2012a).

The results of the particle size analysis corroborated with what the Atterberg limits indicated: silt-clay soils.

\section{Thermal characteristics of soil samples}

The soil samples were treated and submitted to TG and DTA thermal tests. TG, DTG and DTA curves of the SBSM, SJUA and SSCE samples are shown, respectively, in Figure 8, Figure 9 and Figure 10.

By analysing the behaviour of soil samples submitted to heating, it can be observed in the TG curves that there were three defined mass loss events, seen more clearly observing the DTG curves. In an analytical way, the first event, the dehydration of the material or the release of water or its solutions commonly present in soils, occurs up to a temperature of $200{ }^{\circ} \mathrm{C}$, showing losses of $8.425 \%, 6.822 \%$ and $4.273 \%$, respectively, for the SBSM, SJUA and SSCE samples (SILVA et al., 2016). The second event, initiated at $200{ }^{\circ} \mathrm{C}$, 
resulted in mass losses of $7.988 \%$ up to $679{ }^{\circ} \mathrm{C}$ for SBSM, $8.725 \%$ up to $765^{\circ} \mathrm{C}$ for SJUA and $24.376 \%$ up to $880{ }^{\circ} \mathrm{C}$ for SSCE. Until the end of heating, the masses of the samples suffered reductions of $0.663 \%$ in SBSM, $0.710 \%$ in SJUA and $0.262 \%$ in SSCE. The DTG and DTA curves and peaks confirm the events occurring with the heated masses.

Figure 8 - TG, DTG and DTA curves of the SBSM sample

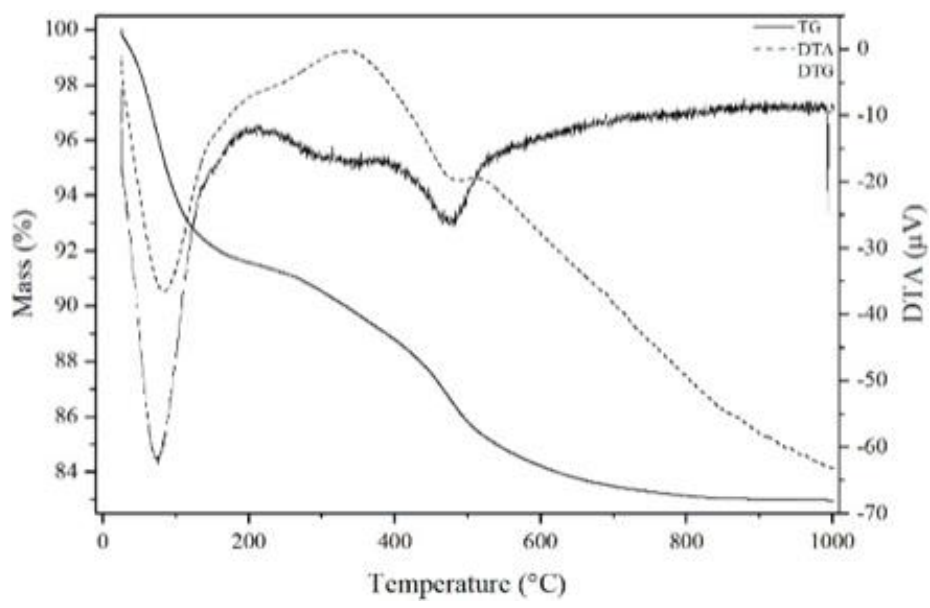

Figure 9 - TG, DTG and DTA curves of the SJUA sample

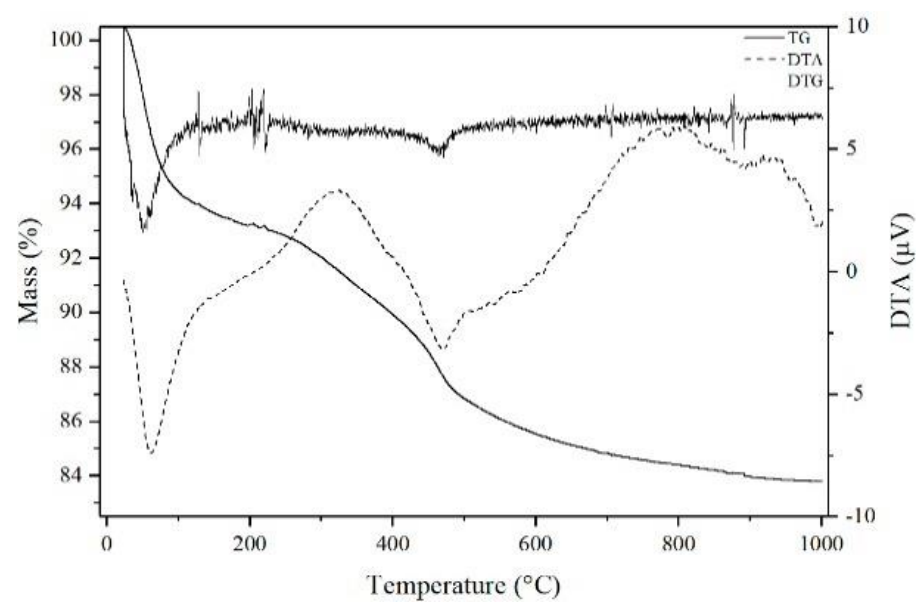

Figure 10 - TG, DTG and DTA curves of the SSCE sample

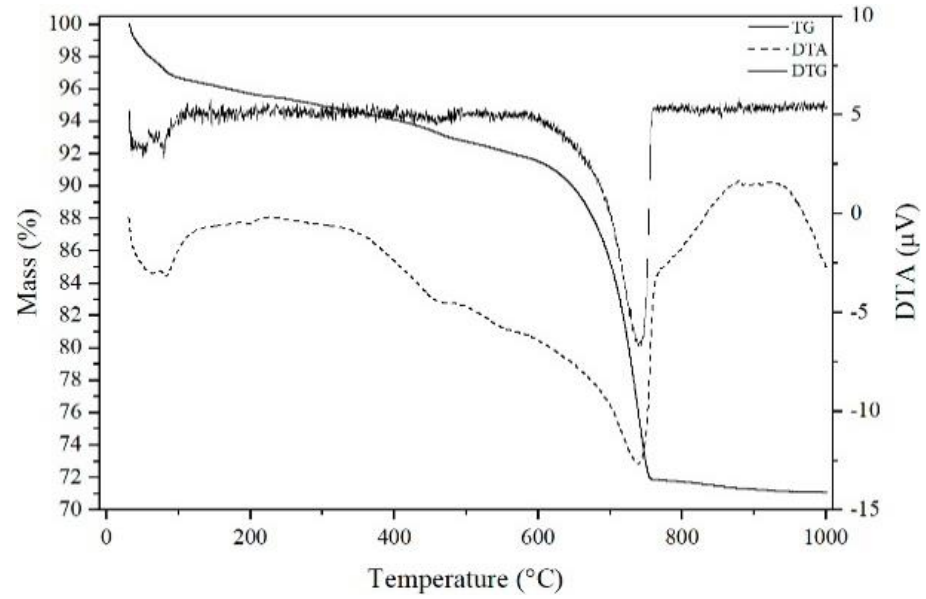


Regarding the aforementioned numbers, it can be stated that the loss to fire totalled $17.076 \%$ for SBSM, $16.257 \%$ for SJUA and $28.911 \%$ for SSCE, in which this mass was associated with free water and volatilized solution and burning of organic matter, showing that the total and the mass losses in the second temperature range analysed were more accentuated for the SSCE sample, which presented, therefore, a higher content of organic matter (GONÇALVES et al., 2017; CARTAXO et al., 2016; DIAS; LIMA, 2004; ABNT, 1996). According to Gonçalves et al. (2017), the peak observed in the DTA curve in the 700 and 800 ${ }^{\circ} \mathrm{C}$ range may be associated with the onset of clay sintering and changes in the crystal structure.

\section{Conclusions}

The compositions of the soil samples from Barra de São Miguel, Juazeirinho and Santa Cecilia were similar, with a predominance of silica, alumina and hematite, comprising about $90 \%$ of each plasticity, as medium plastics, and the granulometry, in the range of "silt-clay", with variations in the thermal behaviour. They meet the standard requirements of soils that produce pressed bricks. The results obtained showed that the raw materials meet the technical specifications required for use in soil-cement bricks (a type of ecological brick) and sealing bricks (the most used in construction). Specifically, for bricks that are produced in a conventional way (with burning), thermal analysis showed masses with behaviour common to those presented by raw materials from the red ceramic industry.

Therefore, the deposits where the samples were collected offer satisfactory raw material for the ceramics industry.

\section{References}

ACCHAR, W.; SILVA, J. E.; SEGADÃES, A. M. Increased added value reuse of construction waste in clay based building ceramics. Advances in Applied Ceramics, v. 112, n. 8, p. 487-493, 2013.

ALONSO-SANTURDE, R. et al. Recycling of foundry by-products in the ceramic industry: green and core sand in clay bricks. Construction and Building Materials, v. 27, p. 97-106, 2012.

AÑóN, J. R. et al. Development of an experimental procedure to analyse the 'soil health state' by microcalorimetry. Journal of Thermal Analysis and Calorimetry, v. 87, p. 15-19, 2007.

ASSOCIAÇÃO BRASILEIRA DE CERÂMICA. Cerâmica no Brasil: considerações gerais. 2015. Available: http://www.abceram.org.br/site/index.php?area=2. Access: 10 Jan. 2019.

ASSOCIAÇÃO BRASILEIRA DE NORMAS TÉCNICAS. NBR 10833: manufacture of brick and block of soil-cement with use of a manual or hydraulic brickmaking machine: procedure. Rio de Janeiro, $2012 \mathrm{a}$.

ASSOCIAÇÃO BRASILEIRA DE NORMAS TÉCNICAS. NBR 13600: soil: determination of organic matter content by igniting at $440{ }^{\circ} \mathrm{C}$ : method of test. Rio de Janeiro, 1996.

ASSOCIAÇÃO BRASILEIRA DE NORMAS TÉCNICAS. NBR 7180: soil: plasticity limit determination. Rio de Janeiro, 2016.

ASSOCIAÇÃO BRASILEIRA DE NORMAS TÉCNICAS. NBR 8491: soil-cement brick: requirements. Rio de Janeiro, $2012 b$.

AYATI, B. et al. Use of clay in the manufacture of lightweight aggregate. Construction and Building Materials, v. 162, p. 124-134, 2018.

BERNATEK-JAKIEL, A.; KACPRZAK, A.; STOLARCZYK, M. Impact of soil characteristics on piping activity in a mountainous area under a temperate climate (Bieszczady Mts., Eastern Carpathians). Catena, v. 141, p. 117-129, 2016

BYRE, K. R. et al. Environmental controls on soil respiration across a southern US climate gradient: a metaanalysis. Geoderma Regional, v. 7, p. 110-119, 2016.

CABRAL JUNIOR, M. et al. Argilas para cerâmica vermelha. In: ROCHAS e minerais industriais. Rio de Janeiro: Centro de Tecnologia Mineral, 2005.

CAPUTO, H. P. Mecânica dos solos e suas aplicações: fundamentos. Rio de Janeiro: LTC, 1988.

CARREIRO, M. E. A. et al. Residue of quartzite: alternative raw material for use in structural ceramics.

Cerâmica, v. 62, p. 170-178, 2016.

120 Queiroz, A. J.; Morais, C. R. da S. 
CARTAXO, J. M. et al. Study of new occurrences of plastic (ball) clays from northeastern Brazil for use in refractory ceramics. Cerâmica, v. 62, p. 338-344, 2016.

CARTER, L. J.; RYAN, J. J.; BOXALL, A. B. A. Effects of soil properties on the uptake of pharmaceuticals into earthworms. Environmental Pollution, v. 213, p. 922-931, 2016.

CHENG, Y. et al. Engineering and mineralogical properties of stabilized expansive soil compositing lime and natural pozzolans. Construction and Building Materials, v. 187, p. 1031-1038, 2018.

COSTA, V. A. F. Improving the thermal performance of red clay holed bricks. Energy and Buildings, v. 70, p. 352-364, 2014.

DIAS, J. C.; LIMA, W. N. Comparação de métodos para a determinação de matéria orgânica em amostras ambientais. Revista Científica da UFPA, v. 4, p. 1-16, 2004.

DOAT, P. et al. CRATerre Construire en terre. Paris: L'Harmattan, 1979.

FEDERAÇÃO DAS INDÚSTRIAS DO ESTADO DE MINAS GERAIS; FUNDAÇÃO ESTADUAL DE MEIO AMBIENTE. Guia técnico ambiental da indústria de cerâmica vermelha. Belo Horizonte: FIEMG, FEAM, 2013.

FRANCO-ANDREU, L. et al. Behavior of two pesticides in a soil subjected to severe drought: effects on soil biology. Applied Soil Ecology, v. 105, p. 17-24, 2016.

GONÇALVES, W. P. et al. Microstructural, physical and mechanical behavior of pastes containing clays and alumina waste. Applied Clay Science, v. 137, p. 259-265, 2017.

GUGGENHEIM, S.; MARTIN, R. T. Definition of clay and clay mineral: joint reporto $f$ the aipea nomenclature and CMS nomenclature committees. Clay and Clay Miner, v. 43, n. 2, p. 255-256, 1995.

HAJJAJI, W. et al. Aqueous acid Orange 7 dye removal by clay and red mud mixes. Applied Clay Science, v. 126, p. 197-206, 2016.

HARTEMINK, A. E. The definition of soil since the early 1800s. Advances in Agronomy, v. 137, p. 73126, 2016.

KERN, J. et al. What can we learn from ancient fertile anthropic soil (Amazonian Dark Earths, shell mounds, Plaggen soil) for soil carbon sequestration? Catena, v. 172, p. 104-112, 2019.

KUČERÍK, J.; ČTVRTNÍČKOVÁ, A.; SIWERT, C. Practical application of thermogravimetry in soil science: part 1: thermal and biological stability of soils from contrasting regions. Journal of Thermal Analyss and Calorimetry, v. 113, n. 3, p. 1103-1111, 2013.

KUNKEL, V.; WELLS, T.; HANCOCK, G. R. Soil temperature dynamics at the catchment scale. Geoderma, v. 273, p. 32-44, 2016.

LESSOVAIA, S. N. et al. Soil development on basic and ultrabasic rocks in cold environments of Russia traced by mineralogical composition and pore space characteristics. Catena, v. 137, p. 596-604, 2016.

LI, N. et al. Development of soil food web of microbes and nematodes under different agricultural practices during the early stage of pedogenesis of a Mollisol. Soil Biology and Biochemistry, v. 98, p. 208-216, 2016.

LIU, T. et al. Low-cost and environment-friendly ceramic foams made from lead-zinc mine tailing sand red mud: Foaming mechanism, physical, mechanical and chemical properties. Ceramics International, v. 42, p. 1733-1739, 2016.

LUZ, A. B. et al. Caulim. In: ROCHAS e minerais industriais. Rio de Janeiro: CETEM-MCT, 2005.

MACEDO, R. S. et al. Study of clays used in red ceramic. Cerâmica, v. 54, p. 411-417, 2008.

MAO, P. et al. Dynamic characteristics of soil properties in a Robinia pseudoacacia vegetation and coastal eco-restoration. Ecological Engineering, v. 92, p. 132-137, 2016.

MARSAN, F. A. et al. Metal release under anaerobic conditions of urban soils of four european cities.

Water, Air and Soil Pollution, v. 230, p. 53-68, 2019.

MASON, E.; THOMPSON, S. K. A brief overview of crystalline silica. Journal of Chemical Health and Safety, v. 17, n. 2, p. 6-8, 2010. 
MENEZES, R. R.; NEVES, G. A.; FERREIRA, H. C. Map of clays of Paraíba State. Cerâmica, v. 47, n. 302, 2001.

MILLIOLI, V. S. et al. Bioremediation of crude oil-bearing soil: evaluating the effect of rhamnolipid addition to soil toxicity and to crude oil biodegradation efficiency. Global NEST Journal, v. 11, n. 2, p. 181-188, 2009.

MYMRIN, V. et al. Red ceramics from composites of hazardous sludge with foundry sand, glass waste and acid neutralization salts. Journal of Environmental Chemical Engineering, v. 4, p. 753-761, 2016.

PALUDO, D.; SANT'ANNA, F. S. P. Impactos ambientais da indústria de cerâmica vermelha. In: SIMPÓSIO INTERNACIONAL DE INICIAÇÃO CIENTÍFICA DA USP, São Paulo, 2003. Anais [...] São Paulo: Universidade de São Paulo, 2003.

PAN, Y. et al. Effect of spatial variability on performance of cement-treated soil slab during deep excavation. Construction and Building Materials, v. 188, p. 505-519, 2018.

PARELHO, C. et al. Assessing microbial activities in metal contaminated agricultural volcanic soils - An integrative approach. Ecotoxicology and Environmental Safety, v. 129, p. 242-249, 2016.

REGUEIRA, L. N. et al. Design of an experimental procedure to assess soil health state. Journal of Thermal Analysis and Calorimetry, v. 85, p. 271-277, 2006.

SALEIRO G. T. Processamento de cerâmica vermelha usando um ciclo rápido de queima. Tempo Técnico, v. 6, p. 16-28, 2010.

SANTOS G. M. Estudo das variáveis de processamento das matérias-primas da região do Crato - CE na fabricação de produtos cerâmicos por extrusão e por prensagem. 2009. Available:

https://repositorio.ufrn.br/jspui/bitstream/123456789/15595/1/GetulioMS.pdf. Access: 12 Jan. 2019.

SANTOS P. S. Ciência e tecnologia de argilas. São Paulo: Edgard Blücher, 1992.

SANTOS R. C. Desenvolvimento de microestrutura de massas da cerâmica vermelha submetidas a diferentes tratamentos térmicos. 2016. Available:

http://dspace.sti.ufcg.edu.br:8080/jspui/bitstream/riufcg/1064/1/RENATO\%20CORREIA\%20DOS\%20SAN TOS\%20-\%20TESE\%20\%28PPGCEMat\%29\%202016.pdf. Access: 20 Jan. 2019.

SILVA, V. J. et al. Porous mullite blocks with compositions containing kaolin and alumina waste. Ceramics International, v. 42, p. 15471-15478, 2016.

STEVENS, M. T.; MCKINLEY, G. B.; VAHEDIFARD, F. A comparison of ground vehicle mobility analysis based on soil moisture time series datasets from WindSat, LIS, and in situ sensors. Journal of Terramechanics, v. 65, p. 49-59, 2016.

TRAN, K. Q.; SATOMI, T.; TAKAHASHI, H. Improvement of mechanical behavior of cemented soil reinforced with waste cornsilk fibers. Construction and Building Materials, v. 178, p. 204-210, 2018.

VAEZI, A. R.; HASANZADEH, H.; CERDÀ, A. Developing an erodibility triangle for soil textures in semi-arid regions. Catena, v. 142, p. 221-232, 2016.

VELDE, B. B.; MEUNIER, A. Fundamentals of Clay Mineral Crystal Structure and Physicochemical Properties. In: THE ORIGIN of clay minerals in soils and weathered rocks. Berlin: Springer, 2008.

VIEIRA, C. M. F.; PINHEIRO, R. M. Avaliação de argilas cauliníticas de Campos dos Goytacazes utilizadas para fabricação de cerâmica vermelha. Cerâmica, v. 57, n. 2, p. 319-323, 2013.

WEISSERT, L. F.; SALMOND, J. A.; SCHEWENDENMANN, L. Variability of soil organic carbon stocks and soil CO2 efflux across urban land use and soil cover types. Geoderma, v. 271, p. 80-90, 2016.

XIA, J. et al. Effects of different groundwater depths on the distribution characteristics of soil-Tamarix water contents and salinity under saline mineralization conditions. Catena, v. 142, p. 166-176, 2016. 


\section{Abílio José Procópio Queiroz}

Centro de Formação em Tecnociências e Inovação | Universidade Federal do Sul da Bahia | Rua Itabuna, s/n, Rodovia Ithéus - Vitória da Conquista, km 39, BR 415, Ferradas | Itabuna - BA - Brasil | CEP 45613-204 | Tel.: (73) 3214-3288 | E-mail: abilio.queiroz@ufsb.edu.br

\section{Crislene Rodrigues da Silva Morais}

Unidade Acadêmica de Engenharia de Materiais | Universidade Federal de Campina Grande | Rua Aprígio Veloso, 882, Universitário | Campina Grande - PB - Brasil | CEP 58428-830 | Tel.: (83) 2101-1544 | E-mail: crislenemorais@yahoo.com.br

\section{Ambiente Construído}

Revista da Associação Nacional de Tecnologia do Ambiente Construído Av. Osvaldo Aranha, $99-3^{\circ}$ andar, Centro

Porto Alegre - RS - Brasil

$$
\text { CEP 90035-190 }
$$

Telefone: +55 (51) 3308-4084

www.seer.ufrgs.br/ambienteconstruido www.scielo.br/ac

E-mail: ambienteconstruido@ufrgs.br 